\title{
Research on mechanical behavior of needle-punched nonwoven fabric
}

DOI: 10.35530/IT.069.03.1410

\section{REZUMAT - ABSTRACT}

\section{Studiu asupra comportamentului mecanic al materialelor textile neţesute interţesute}

Au fost studiate proprietățile anizotropice ale comportamentului de rezistență la tracțiune și fluaj al materialelor textile nețesute. Au fost analizate experimental influențele lățimii probei și direcția distribuirii fibrelor asupra comportamentului la tracțiune al materialelor textile nețesute, interțesute. Rezultatul arată că lățimea probei are o influență importantă asupra comportamentului de tracțiune. A fost investigat comportamentul anizotropic de fluaj al materialelor textile nețesute, interțesute, adică influențele tensiunii și unghiului față de directia mașinii (MD) asupra fluajului. Relația dintre alungirea la fluaj și timpul la diferite tensiuni și unghiuri diferite față de direcția mașinii (MD) a materialelor textile nețesute, interțesute se obține prin aplicarea unei fixări liniare și se deduce modelul empiric pentru calculul alungirii la fluaj. Rezultatul are o semnificație importantă pentru predicția comportamentului mecanic, cum ar fi comportamentul de rezistență la tracțiune, fluaj și relaxare a materialelor textile nețesute, interțesute și reducerea cheltuielilor experimentale și a dificultăților.

Cuvinte-cheie: materiale textile interțesut, fluaj, rezistență la tracțiune, anizotropic, lățimea probei

\section{Research on mechanical behavior of needle-punched nonwoven fabric}

The anisotropic properties in tensile and creep behavior of needle-punched nonwoven fabric are studied in this paper. The influences of specimen width and direction of fiber distribution on the tensile behavior of needle-punched nonwoven fabric are experimental analyzed. The result shows that the specimen width has important influence on tensile behavior. The anisotropic creep behavior of needle-punched fabric i.e., the influences of stress and the angle with the machine direction (MD) on creep is investigated. The relationship between creep elongation and time at different stress and different angle with the machine direction (MD) of needle-punched fabric are obtained by applying linear fitting and the empirical model for calculating creep elongation are deduced. The result has an important meaning for predicting the mechanical behavior, such as tensile, creep and relaxation behavior of needle-punched nonwoven fabric and reducing experimental expense and difficulty.

Keywords: needle-punched fabric, creep, tensile, anisotropic, specimen width

\section{INTRODUCTION}

As a permeable textile structures made of polymeric materials, needle-punched nonwoven fabric is usually used in civil engineering. In contrast to knitted fabric and woven fabric, the random and discontinuous microstructure is the most characteristic features of nonwoven. Due to its discontinuous and non-uniform microstructure, the dimension of specimen plays an important role to its tensile behavior, and different size specimens may demonstrate different type of material behavior [1-2]. Hou, et al. analyzed the influences of the specimen size and shape factor (the ratio of the specimen's length to its width) on mechanical property of thermally bonded nonwoven by means of uniaxial tensile tests [3]. Therefore, it is necessary to study the influence of specimen width on nonwoven tensile behavior.

Mechanical properties in tensile and creep behavior of needle-punched nonwoven fabric are of considerable interest for their satisfactory performance in constructional materials. Due to the complex structure of nonwoven fabrics, some researchers had used considerable efforts to understand the mechanical behavior of nonwoven. For example, Gautier, et al. studied the anisotropic mechanical behavior of needle-punched and thermo-bonded nonwoven fabric by means of uniaxial tensile tests [4]. Debnath, et al. investigated the anisotropy behavior of needlepunched parallel laid jute non-woven [5]. Debnath and Madhusoothanan investigated the compression creep behavior of needle-punched nonwoven with different constituent fibers based on experiment $[6,7]$. Since mechanical behavior of nonwoven fabric is influenced by fiber property and its distribution, some Refs. [8-12] investigated the relationship between the mechanical behavior of nonwoven fabric and the constituent fibers. Therefore the mechanical property of nonwoven fabric could be predicted by using the structural parameters of nonwoven fabrics and the behavior of fiber. Kothari and Patel developed a mechanical model to predict the creep behavior of nonwoven fabric using the fiber creep result and structural parameters of the fabric [13].

When constant stress is subjected to nonwoven fabric, there is a creep elongation. The ability of the material to withstand loads without excessive creep is a major factor in material selection and design of 
geotextile. In order to improve the creep behavior of needle-punched nonwoven fabric, the anisotropy creep behavior i.e., stresses and the angle with the machine direction (MD) on creep is investigated. Das, et al. studied the anisotropy creep behavior of thermo-bonded spun laid nonwoven fabric and observed that the creep of nonwoven depends on the fiber direction, level of load [14]. The same method has been implemented in this article to analyze the anisotropy tensile and creep behavior of needlepunched nonwoven fabric.

In this paper, the anisotropy tensile and creep behavior of needle-punched nonwoven fabric are investigated using wide-width strip tensile and creep test. The influences of specimen width and different angle in the machine direction (MD) of needle-punched fabric are investigated. The influences of different levels of load and different angle in the machine direction on creep behavior of needle-punched nonwoven fabric are analyzed and the empirical equations of calculating creep elongations at different conditions are obtained by applying linear fitting.

\section{MATERIALS PROPERTIES}

The needle-punched nonwoven fabric, manufactured using polypropylene fiber ( $3.10 \mathrm{dtex}, 38 \mathrm{~mm}$ ) by penetrating the fibrous web with needle were used for the study. The nominal thickness, density and needle density of nonwoven fabric are $3.28 \mathrm{~mm}, 447.11 \mathrm{~g} / \mathrm{m}^{2}$ and 346 penetrations $/ \mathrm{cm}^{2}$, respectively. The SEM images of the needle-punched nonwoven fabric are shown in figure 1.

\section{TENSILE TESTING}

The effect of the specimen width

Due to the non-uniform microstructure and material properties of the fabric, different size of specimens may result in different behavior. To investigate the effect of the width, specimens of nonwoven fabric with three different widths were tested using INSTON Universal Testing Machine under standard laboratory condition (20,65\% relative humidity).

The tensile behavior of nonwoven with different width was carried out using 10 nonwoven specimens at a gauge of $100 \mathrm{~mm}$ clamp distance and a speed of $50 \mathrm{~mm} / \mathrm{min}$. The tensile behavior was studied at different angles in the machine direction (MD) of fabrics, i.e., $0^{\circ}, 30^{\circ}, 60^{\circ}$ and $90^{\circ}$ (CD).

The tensile results of nonwoven fabric with different widths and different angles are shown in table 1.

As shown in figure 2, the tensile strength will be varied with increasing of specimen width. When the width of nonwoven is $100 \mathrm{~mm}$, the tensile strength has maximum value. Due to anisotropy of the properties of the nonwoven material, its tensile behavior is highly dependent on fiber distribution.

The effect of angles in the machine direction (MD) Due to anisotropy properties of the nonwoven material, its tensile behavior is highly sensitive to fiber distribution. It can be obtained that the tensile strength

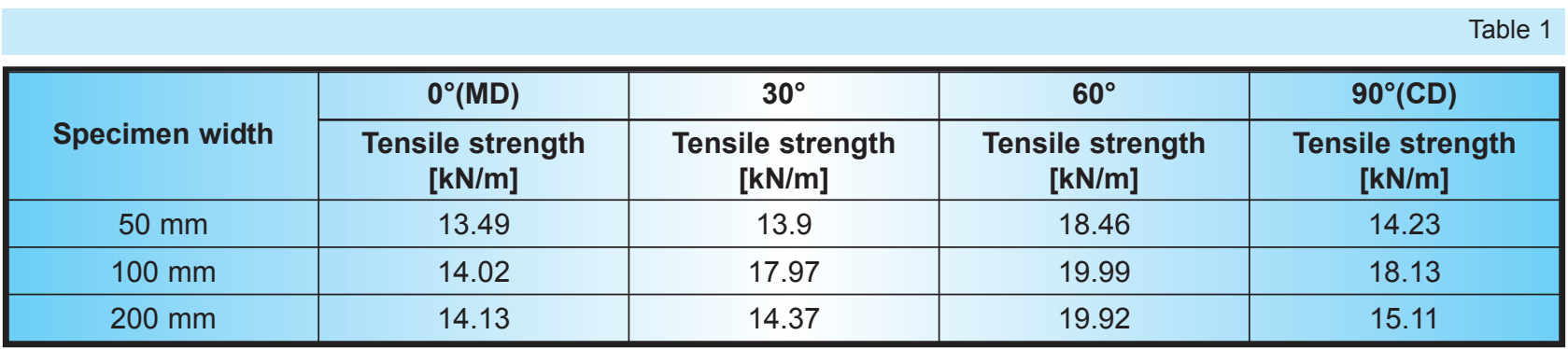

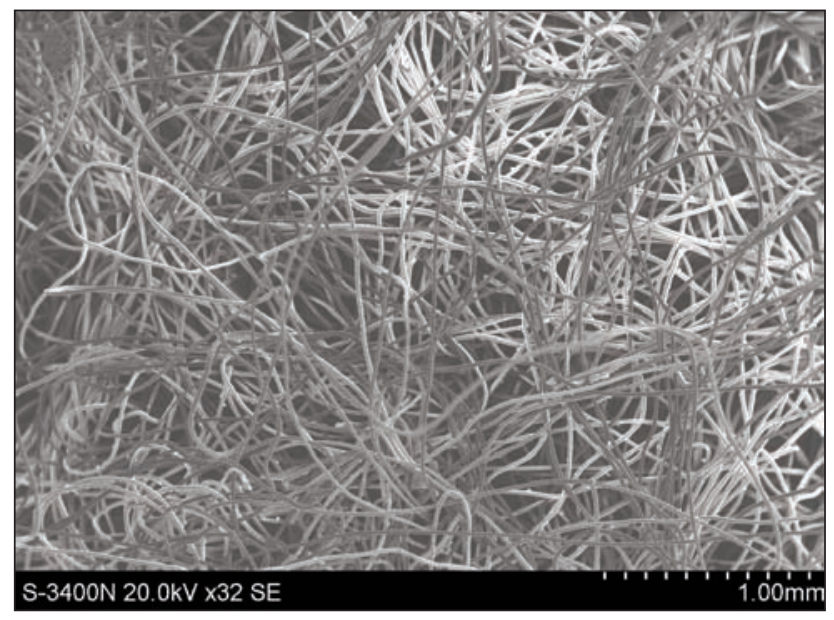

a

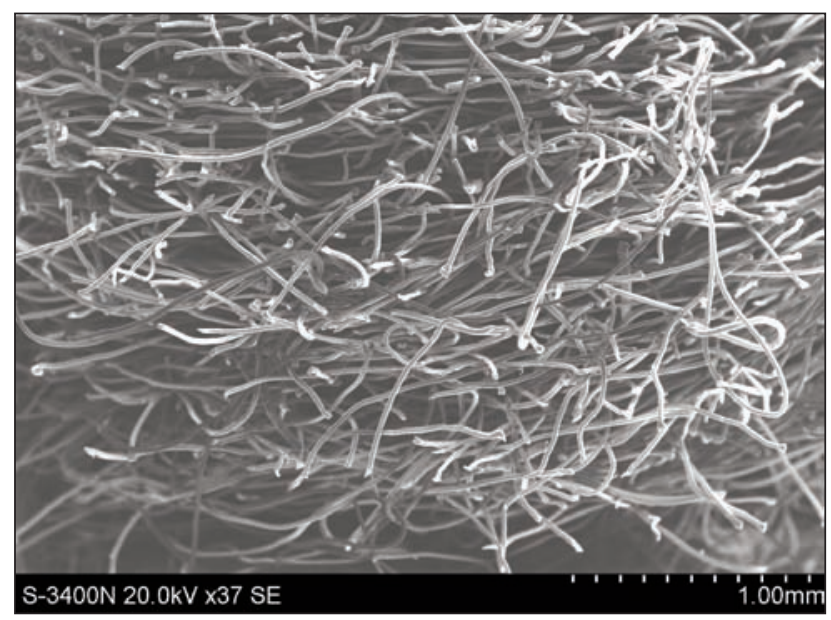

b

Fig. 1. SEM image of the needle-punched nonwoven fabric: $a$ - fiber distribution in plane; $b$ - fiber distribution in thickness 


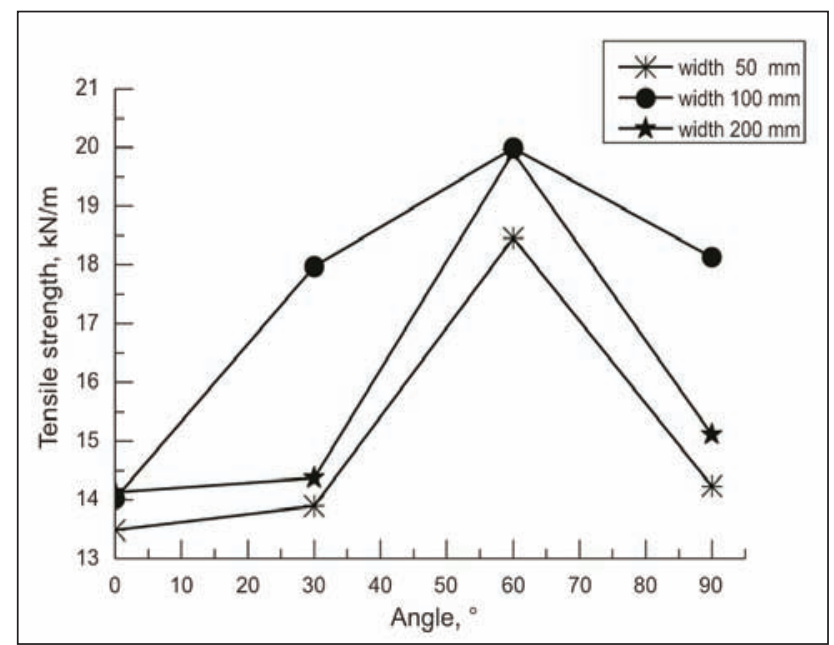

Fig. 2. The tensile behavior of needle-punched nonwoven fabric at different width and angle

is also proportional to the fiber distribution. With respect to figure 2 , it can be concluded that the tensile strength at $60^{\circ}$ in the machine direction (MD) of fabrics has maximum value no matter the width of specimen. The tensile strength has maximum value in the direction of maximum fibers in the fabric, i.e. $60^{\circ}$ direction. Least fibers are aligned in the $30^{\circ}$ and $90^{\circ}$ directions.

\section{ANISOTROPY CREEP OF NEEDLE-PUNCHED NONWOVEN FABRIC}

When the amount of loading is increased the amount of creep will be increased, which has effect on fatigue of needle-punched nonwoven fabric. In order to improve the creep behavior of nonwoven, it is necessary to study the anisotropy creep behavior, i.e., the influences of stress and the angle in machine direction on creep.

Nonwoven creep test were carried out on INSTON Universal Testing Machine using specimens $(200 \mathrm{~mm}$ $\times 200 \mathrm{~mm}$ ) at a gauge of $100 \mathrm{~mm}$ clamp distance and a speed of $50 \mathrm{~mm} / \mathrm{min}$. The creep behavior of every specimen with different angle and stress was repeated 10 times.

\section{The creep behaviour at varying load at constant angle}

The creep behaviors of nonwoven fabric at different levels of loading, i.e., $30 \%, 45 \%$ and $60 \%$ of tensile strength in the relevant direction are executed. The elongations subjected to loading are recorded at different time intervals, i.e., $30 \mathrm{sec}, 1 \mathrm{~min}, 2 \mathrm{~min}, 3 \mathrm{~min}$, $5 \mathrm{~min}, 10 \mathrm{~min}, 15 \mathrm{~min}$ and $30 \mathrm{~min}$. The experimental results are shown in tables 2, 3 and 4.

The creep elongation will be increased due to the increasing of loading in particular direction, which one can observe from figure 3 .

It can be concluded that the creep elongation is proportional to the level of loading and time. The initial extension is instantaneously increases and finally stabilizing at a limiting extension value. With the increasing of loading the creep increases, since the higher load would increase definitely the fiber-to-fiber slippage and also execute higher force on the individual fibers which result in higher creep elongation.

Table 2

\begin{tabular}{|c|c|c|c|c|c|c|c|c|}
\hline \multirow{2}{*}{$\begin{array}{l}\text { Load } \\
\text { [MPa] }\end{array}$} & & \multicolumn{7}{|c|}{ Time [s] } \\
\hline & & 30 & 60 & 120 & 300 & 600 & 900 & 1800 \\
\hline $30 \%(1.38 \mathrm{MPa})$ & \multirow{3}{*}{$\begin{array}{c}\text { Extension } \\
{[\mathrm{mm}]}\end{array}$} & 18.27 & 18.28 & 18.31 & 18.37 & 18.41 & 18.43 & 18.47 \\
\hline $45 \%(2.07 \mathrm{MPa})$ & & 26.32 & 26.37 & 26.45 & 26.56 & 26.67 & 26.81 & 26.92 \\
\hline $60 \%$ (2.76 MPa) & & 46.12 & 46.15 & 46.19 & 46.24 & 46.29 & 46.37 & 46.46 \\
\hline
\end{tabular}

Table 3

\begin{tabular}{|c|c|c|c|c|c|c|c|c|}
\hline \multirow{2}{*}{$\begin{array}{l}\text { Load } \\
\text { [MPa] }\end{array}$} & & \multicolumn{7}{|c|}{ Time [s] } \\
\hline & & 30 & 60 & 120 & 300 & 600 & 900 & 1800 \\
\hline $30 \%(1.31 \mathrm{MPa})$ & \multirow{3}{*}{$\begin{array}{c}\text { Extension } \\
{[\mathrm{mm}]}\end{array}$} & 37.21 & 37.25 & 37.29 & 37.35 & 37.48 & 37.57 & 37.73 \\
\hline $45 \%(1.97 \mathrm{MPa})$ & & 44.87 & 44.91 & 44.99 & 45.13 & 45.27 & 45.34 & 45.44 \\
\hline $60 \%(2.63 \mathrm{MPa})$ & & 57.51 & 57.55 & 57.59 & 57.70 & 57.76 & 57.85 & 57.93 \\
\hline
\end{tabular}

Table 4

\begin{tabular}{|c|c|c|c|c|c|c|c|c|}
\hline \multirow{2}{*}{$\begin{array}{l}\text { Load } \\
\text { [MPa] }\end{array}$} & & \multicolumn{7}{|c|}{ Time [s] } \\
\hline & & 30 & 60 & 120 & 300 & 600 & 900 & 1800 \\
\hline $30 \%(1.82 \mathrm{MPa})$ & \multirow{3}{*}{$\begin{array}{c}\text { Extension } \\
{[\mathrm{mm}]}\end{array}$} & 33.54 & 33.59 & 33.67 & 33.74 & 33.81 & 33.92 & 33.99 \\
\hline $45 \%(2.73 \mathrm{MPa})$ & & 45.89 & 45.94 & 46.11 & 46.19 & 46.27 & 46.34 & 46.49 \\
\hline $60 \%$ (3.64 MPa) & & 54.10 & 54.23 & 54.35 & 54.47 & 54.63 & 54.78 & 54.89 \\
\hline
\end{tabular}



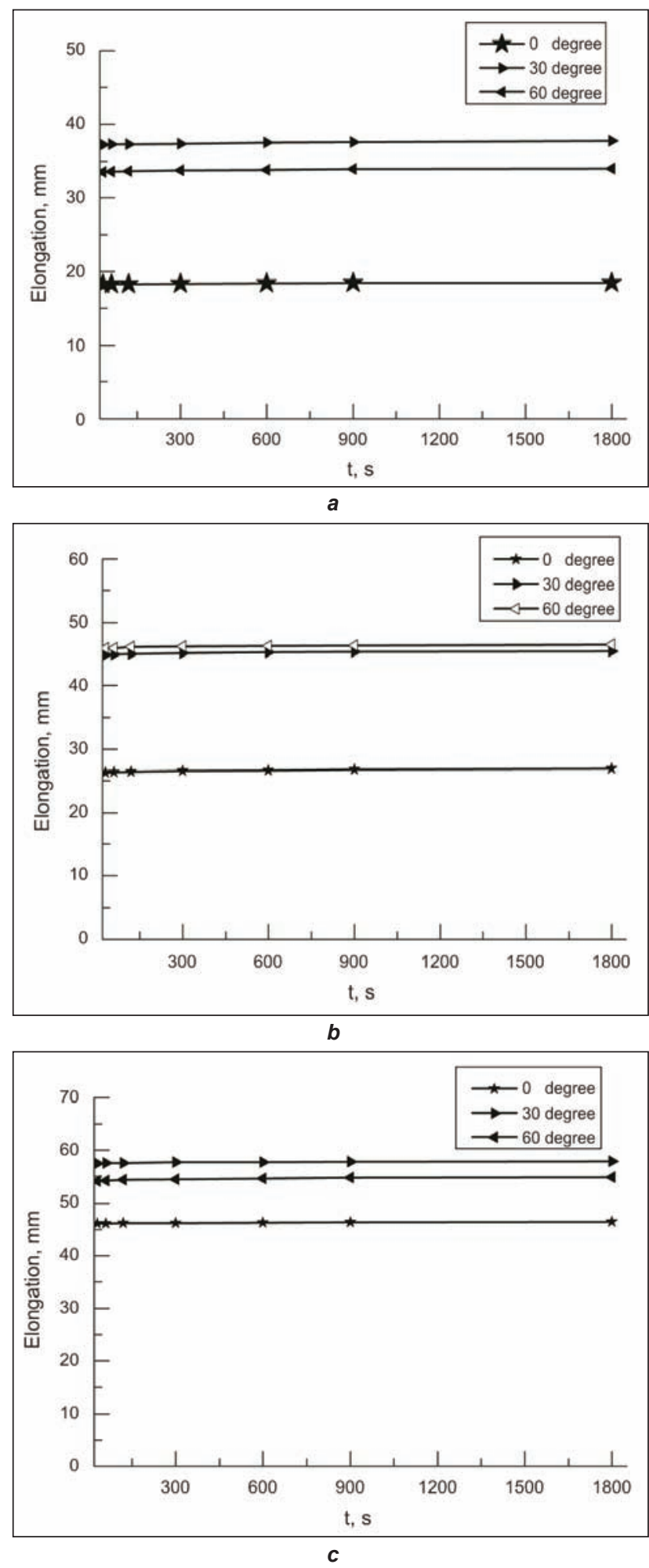

Fig. 3. Anisotropy in creep behavior of needle-punched nonwoven fabric at different level of loading and angle in machine direction: $a-30 \% ; b-45 \% ; c-60 \%$

\section{The creep behaviour at varying direction of loading at constant load}

The anisotropic creep behavior of needle-punched nonwoven fabric is studied at different angles in the machine direction (MD) of fabrics, i.e., $0^{\circ}, 30^{\circ}$ and $60^{\circ}$, is shown in figure 3 . It can be seen that all the curves follow similar trend with a difference in instantaneous extension. The initial elongation at machine direction is lesser than that in $30^{\circ}$ and $60^{\circ}$ directios, since the fiber distribution at machine direction has more than that in other directions. The maximum extension is observed in a direction with minimum number of fibers and minimum creep extension is occurred for the sample having maximum number of fibers. The creep extension will be decreased continuously with increasing number of fibers in the direction of loading.

The creep extension of nonwoven fabric is found to be affected by the fiber distribution and amount of loading. The relationship between creep elongation and time at different stress and different angles in machine direction of needle-punched fabric is obtained by applying linear fitting and the empirical model for calculating creep elongation is deduced, as shown in table 5. The results show that the creep of needlepunched nonwoven fabrics follow linear relationships with logarithm of time and this is true for all the directions of loading and for all the levels of loading.

Table 5

\begin{tabular}{|c|c|c|c|}
\hline $\begin{array}{c}\text { Direction } \\
\text { of loading } \\
\text { [degree] }\end{array}$ & $\begin{array}{c}\text { Level of } \\
\text { loading } \\
{[\%]}\end{array}$ & Relationships & $\mathbf{R}^{2}$ \\
\hline \multirow{4}{*}{0} & $30 \%$ & $y=18.08+0.12 x$ & 0.979 \\
\cline { 2 - 4 } & $45 \%$ & $y=25.77+0.34 x$ & 0.957 \\
\cline { 2 - 4 } & $60 \%$ & $y=45.82+0.18 x$ & 0.925 \\
\hline \multirow{4}{*}{30} & $30 \%$ & $y=36.74+0.28 x$ & 0.895 \\
\cline { 2 - 4 } & $45 \%$ & $y=44.32+0.34 x$ & 0.978 \\
\cline { 2 - 4 } & $60 \%$ & $y=57.12+0.24 x$ & 0.966 \\
\hline \multirow{3}{*}{60} & $30 \%$ & $y=33.14+0.25 x$ & 0.971 \\
\cline { 2 - 4 } & $45 \%$ & $y=45.39+0.33 x$ & 0.977 \\
\cline { 2 - 4 } & $60 \%$ & $y=53.43+0.44 x$ & 0.984 \\
\hline
\end{tabular}

\section{CONCLUSIONS}

The effects of specimen width and fiber distribution on tensile properties of needle-punched nonwoven fabric were investigated. The result shows that the tensile behavior is influenced by specimen width and fiber distribution.

The anisotropic creep behavior of needle-punched fabric i.e., the influences of stress and the different angles in machine direction on creep behavior were investigated. The creep test of the nonwoven fabric shows that the creep elongation is dependent on the fiber arrangement and has minimum value in the direction in which the proportion of fiber has maximum value and vice versa. The creep elongation of needle-punched nonwoven has linear relationship with logarithm of time no matter the directions and levels of loading.

\section{ACKNOWLEDGEMENT}

The authors acknowledge with thanks the financial supports from the Natural Science Foundation of Inner Mongolia under grant No.2012MS0811, the key project of Inner Mongolia University of Technology (No. ZD201419) and the youth foundation of Inner Mongolia University of Technology. 


\section{BIBLIOGRAPHY}

[1] Adanur, S., Liao, T.Y. Fiber arrangement characteristics and their effects on nonwoven tensile behavior, In: Textile Research Journal, 1999, vol. 69, no. 11, pp. 816-824.

[2] Ridruejo, A., Gonzalez, C., Llorca, J. Micromechanisms of deformation and fracture of polypropylene nonwoven fabrics, In: International Journal of Solids and Structures, 2011, vol. 48, no. 1, pp. 153-162.

[3] Hou, X.N., Acar, M., Silberschmidt, V.V. Tensile behavior of low density thermally bonded nonwoven material, In: Journal of Engineered Fibers and Fabrics, 2009, vol. 4, no. 1, pp. 26-33.

[4] Gautier, K.B., Kocher, C.W., Drean, J.Y. Anisotropic mechanical behavior of nonwoven geotextiles stressed by uniaxial tension, In: Textile Research Journal, 2007, vol. 77, no. 1, pp. 20-28.

[5] Debnath, C.R., Roy, A.N., Ghosh, S.N. Anisotropy behaviour of needle-punched parallel laid jute non-woven, In: Indian Journal of Fiber \&Textile Research, 1996, vol. 21, no. 4, pp. 244-250.

[6] Debnath, S., Madhusoothanan, M. Compression creep behaviour of polyester needle-punched nonwoven fabrics, In: Journal of The Textile Institute, 2012, vol. 103, no. 12, pp. 1328-1334.

[7] Debnath, S., Madhusoothanan, M. Compression creep behaviour of jute-polypropylene blended needle-punched nonwoven, In: Textile Research Journal, 2012, vol. 82, no. 20, pp. 2116-2127.

[8] Kothari, V., Patel, P. Relationship between tensile properties of fibres and nonwoven fabrics, In: Indian Journal of Fiber \& Textile Research, 2001, vol. 26, no. 4, pp. 398-402.

[9] Rawal, A., Priyadarshi, A., Kumar, N., et al. Tensile behaviour of nonwoven structures: comparison with experimental results, In: Journal of Materials Science, 2010, vol. 45, no. 24, pp. 6643-6652.

[10] Hou, X.N., Acar, M., Silberschmidt, V.V., Finite element simulation of low-density thermally bonded nonwoven materials: Effects of orientation distribution function and arrangement of bond points, In: Computational Materials Science, 2011, vol. 50, no. 4, pp. 1292-1298.

[11] Rawal, A., Lomov, S., Ngo, T., et al. Mechanical behavior of Thru-air bonded nonwoven structures, In: Textile Research Journal, 2007, vol. 77, no. 6, pp. 417-431.

[12] Lee, S.H., Kang, T.J. Mechanical and impact properties of needle punched nonwoven composites, In: Journal of Composite Materials, 2000 , vol. 34, no. 10, pp. 816-840.

[13] Kothari, V., Patel, P. Theoretical model for predicting creep behaviour of nonwoven fabrics, In: Indian Journal of Fiber \& Textile Research, 2001, vol. 26, no. 3, pp. 273-279.

[14] Das, A., Kothari, V K., Kumar, A., et al. Study on anisotropic creep behavior of nonwoven geotextiles, In: Textile Research Journal, 2005, vol. 6, no. 4, pp. 313-317.

\section{Authors: \\ WU WEI \\ GAO XIAOPING}

Inner Mongolia University of Technology, College of Light Industry and Textile, No 0637 Electric Building of Jinchuan Campus of Inner Mongolia University of Technology, Jinchuan economic-tech development zone, 010051, Hohhot, Inner Mongolia, China

e-mail: 978865765 @qq.com, +864713603443

Corresponding author:

GAO XIAOPING

e-mail:gaoxp@imut.edu.cn 